\title{
Perubahan Konstitusi Dalam Transisi Orde Baru Menuju Reformasi Di Indonesia
}

\author{
Fikrotul Jadidah \\ Magister Ilmu Hukum \\ Universitas Indonesia \\ Fikrotul.jadidah17@gmail.com
}

\begin{abstract}
Abstrak. Perubahan konstitusi merupakan salah satu cara terpenting yang dilakukan oleh beberapa rezim transisi untuk mendirikan pemerintahan yang demokratis. Indonesia menghadai momen kritis dalam mengelola transisi politik setelah rezim otoriter Orde baru selama 32 (tiga puluh dua) tahun menuju reformasi yang demokratis. Dalam penelitian jurnal ini perumusan yang dibahas adalah : bagaimana kedudukan konstitusi yang lama terhadap konstruksi hukum rezim yang baru pada masa transisi politik reformasi di Indonesia dan dampak dari perubahan konstitusi dalam transisi orde baru menuju reformasi di Indonesia. Penelitian ini bertujuan untuk mengetahui, menganalisis dan memahami posisi ideal kedudukan konstitusi yang lama terhadap konstruksi hukum rezim yang baru dalam transisi politik menuju demokrasi dan dampak perubahan konstitusi pada transisi orde baru menuju reformasi di Indonesia pada masa kini. Hasil penelitian memperlihatkan bahwa pada masa transisi orde baru menuju reformasi, tidak terjadi perubahan terhadap pembukaan Undang-Undang Dasar Negara Republik Indonesia Tahun 1945 yang isinya memuat Pancasila. Pancasila merupakan dasar falsafah bangsa Indonesia, norma fundamental (grundnorm) bagi Indonesia. Jadi pada masa transisi otoriter menuju demokrasi di Indonesia, tidak diperlukan konstitusi yang benar-benar baru mengingat norma tertinggi yang masih berlaku sehingga yang diperlukan hanya merevitalisasikan konstitusi yang lama untuk keluar dari jerat pola represif menuju pola baru, yakni responsif. Arah politik hukum di Indonesia pasca reformasi adalah keinginan untuk membentuk sistem hukum yang responsif, hal ini secara tersirat dapat dilihat dalam beberapa perubahan pada konstitusi.
\end{abstract}

\section{Kata Kunci : Konstitusi, Reformasi, Indonesia}

Abstract. Constitutional reform are one of the most important ways undertaken by several transitional regimes to establish democratic governance. Indonesia faces a critical moment in managing the political transition after the authoritarian regime of the New Order for 32 (thirty two) years towards democratic reform. In this research journal, the formulation discussed is: how the position of the old constitution towards the legal construction of the new regime during the political transition to reform in Indonesia and the impact of constitutional changes in the transition of the new order towards reform in Indonesia. This study aims to find out, analyze and understand the ideal position of the old constitutional position on the construction of the new regime's law in the political transition to democracy and the impact of constitutional change on the transition of the new order to reform in Indonesia at the present time. The results showed that during the transition of the new order to reform, there was no change in the opening of the 1945 Constitution of the Republic of Indonesia which contained Pancasila. Pancasila is the basic philosophy of the Indonesian nation, the fundamental norm (grundnorm) for Indonesia. So during the authoritarian transition to democracy in Indonesia, there is no need for a completely new constitution given the highest norms that still apply so that what is needed is only revitalizing the old constitution to get out of the trap of repressive patterns towards new patterns, namely responsiveness. The direction of political politics in Indonesia after the reformation is the desire to establish a responsive legal system, this can be implicitly seen in several changes to the constitution.

Keywords: Constitution, Reform, Indonesia 


\section{PENDAHULUAN \\ Latar Belakang}

Semenjak tahun 1970-an, telah terdapat gelombang pasang yang nyata dari demokrasi-demokrasi baru yang muncul dari negara-negara yang masa lalunya bersifat otoriter atau totaliter. Gelombang ini melibatkan banyak negara mulai dari Eropa, Afrika, Amerika hingga ke Asia Tenggara. Transisi politik dari era orde baru menuju reformasi yang dialami oleh Indonesia merupakan salah satu bentuk transisi politik menuju demokrasi yang terjadi di dunia saat itu meskipun penyematan status otoriter terhadap mantan Presiden Soeharto masih menimbulkan pro dan kontra di masyarakat.

Gejolak krisis moneter dunia pada tahun 1997 kemudian mencapai puncaknya bagi Indonesia ketika Presiden Soeharto dipaksa turun lewat sebuah gerakan besar yang dipimpin oleh mahasiswa. Abdul Halim dalam artikelnya menjelaskan bahwa Suharto menjabat Presiden dalam usia cukup muda 46 tahun dengan pangkat Jenderal bintang tiga dan berkuasa tiada tanding tiada banding selama 32 tahun. Semua lawan politiknya dibuat tidak berkutik dengan kekuasaan otoriternya dan kelihaiannya dalam berpolitik. Lebih lanjut Samuel P. Huttington menjelaskan bahwa proses transisi menuju demokrasi ini sangat bervariasi, dimana salah satunya adalah bergejolaknya gerakan reformis yang kemudian mengambil inisiatif untuk mendorong terjadinya transisi. Terkait dengan pro dan kontra mengenai penyematan status otoriter bagi Soeharto, pendapat dari Abdul Halim dan Samual P. Huttington memberikan satu dukungan logis dimana gerakan mahasiswa sebagai reformis dalam upaya mendorong transisi telah memperkuat argumen bahwa rezim Soeharto adalah rezim yang otoriter sehingga ada keinginan bersama dari rakyat yang diinisiasi oleh para mahasiswa untuk melakukan perubahan. Dengan ini jelas sudah bahwa di Indonesia sendiri telah terjadi proses transisi peralihan sistem dari otoriter menuju demokrasi, sebuah proses yang akan melibatkan perubahan konstitusi yang akan menjadi fokus dari makalah ini.

Penafsiran yang banyak diakui mengenai pengertian dasar dari demokrasi adalah bahwa demokrasi merupakan pemerintahan berdasarkan keinginan mayoritas masyarakat. Hal ini menunjukkan bahwa adanya keinginan bersama dari masyarakat sebagai salah satu sumber hukum. Reifikasi yang maksimal dari organisasi kehidupan bersama itu terwujud dalam politik. Konstruksi ini menunjukkan bahwa ada intervensi politik dalam pembentukan hukum di negara demokrasi. Kondisi hubungan antara politik dan hukum ini pada tatanan ilmu hukum saat ini disebut sebagai "Politik Hukum".

Menurut Moh. Mahfud MD, politik hukum merupakan pilihan tentang hukumhukum yang akan diberlakukan sekaligus pilihan tentang hukum-hukum yang akan dicabut atau tidak diberlakukan yang kesemuanya dimaksudkan untuk mencapai tujuan negara seperti yang tercantum di dalam Pembukaan UUD 1945. Transisi kekuasaan tentu erat kaitannya dengan kepentingan politik dari rezim yang baru, kaitannya dengan pendapat Moh. Mahfud MD mengenai pilihan-pilihan hukum yang akan diberlakukan sekaligus hukum yang akan dicabut adalah bahwa transisi politik akan sangat mungkin pada perubahan konstitusi yang merupakan dasar hukum fundamental bagi proses berjalannya pemerintahan di suatu negara.

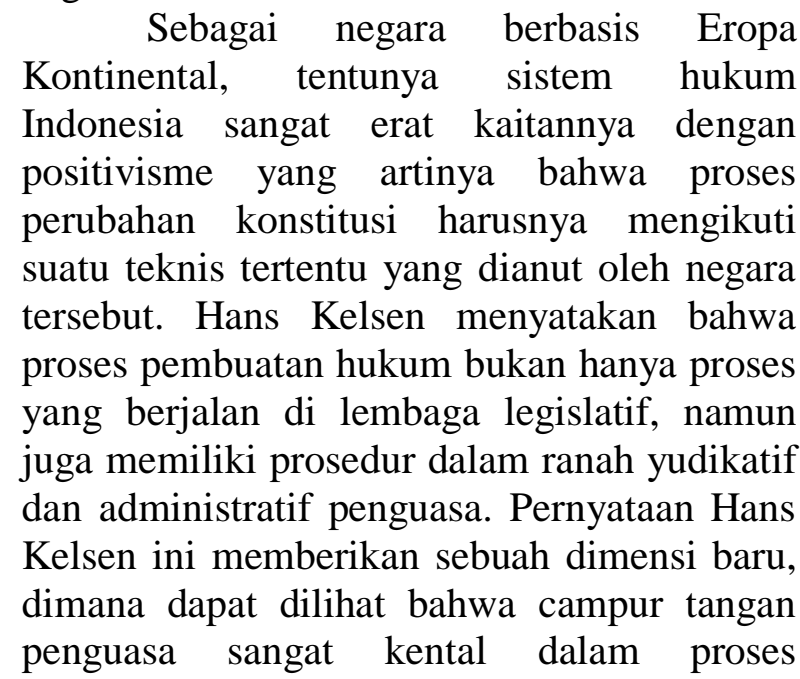


pembentukan produk hukum. Artinya, pergantian penguasa akan berdampak juga pada pergantian konstitusi, karena adanya perubahan pemikiran dari pemimpin yang lama ke yang baru, kepemimpinan erat kaitannya dengan politik hukum, singkatnya, dapat disimpulkan bahwa politik hukum akan memiliki peran yang sangat besar pada proses peralihan konstitusi akibat dari transisi politik suatu negara.

Salah satu perdebatan yang muncul dalam transisi politik menuju demokrasi adalah mengenai kedudukan hukum yang ditinggalkan oleh rezim yang lampau, khususnya dalam menangani penjahat perang kolaborator Nazi. Perdebatan ini mengerucut pada dua pendapat dari H.L.A Hart dan Fuller. Menurut Hart, hukum tertulis yang berlaku sebelumnya walaupun tidak bermoral, tetap harus dinyatakan berlaku dan harus diikuti oleh pengadilan-pengadilan sesudahnya hingga ia dinyatakan tidak berlaku atau diganti dengan yang baru.

Bertentangan dengan Hart adalah Fuller yang berpendapat bahwa aturan hukum mengandung arti bahwa ia juga memutuskan hubungan dengan rezim hukum Nazi. Karenanya, para mantan kolaborator Nazi harus diadili dengan dasar hukum yang baru. Jadi, Fuller berpendapat bahwa jatuhnya suatu rezim ikut menjatuhkan sistem hukum yang dianut beserta produk-produknya sehingga diperlukan produksi hukum mulai dari awal lagi. Meskipun perdebatan ini mengenai Nazi, penulis lalu mengeksplorasi perdebatan ini kepada proses transisi yang terjadi di Indonesia untuk melihat bagaimana kedudukan hukum yang merupakan hasil pemerintahan rezim Soeharto terhadap rezim baru di era reformasi. Nantinya kedua teori ini akan dibandingkan dengan menggunakan teori hukum dari Hans Kelsen. Meskipun Kelsen akan lebih condong mendukung pendapat H.L.A Hart, namun hal ini harus dilakukan mengingat posisi Indonesia yang menggunakan hukum peninggalan Belanda, negara dengan corak Eropa Kontinental yang erat hubungannya dengan paham positivism yang kuat, sehingga sangat sesuai apabila teori Kelsen digunakan sebagai acuan untuk melihat posisi ideal dari perdebatan ini.
Dalam sejarahnya, Indonesia pernah mengalami beberapa kali penggantian konstitusi, diantaranya:

1. Perubahan naskah "Hukum Dasar" hasil karya Dokuritsu Zyunbi Tyoosakai mendjadi Undang-undang Dasar Proklamasi )1945) kemudian diganti menjadi;

2. Konstitusi Sementara Republik Indonesia Serikat (1949) kemudian diganti menjadi;

3. Undang-undang Dasar Sementara 1950 sampai dengan kembali lagi kepada;

4. Undang-undang Dasar 1945 melalui Dekret Presidan 5 Juli 1959.

Selain penggantian, konstitusi Indonesia juga pernah mengalami empat kali perubahan konstitusi selama 2 tahun (19992002) yakni perubahan I-IV Undang-undang Dasar Negara Republik Indonesia 1945. Pada titik inilah kemudian penulis akan melakukan analisis terhadap bagaimana proses perubahan konstitusi pada era transisi politik di Indonesia, karena amandemen terhadap konstitusi dilakukan oleh rezim yang baru untuk membentuk dimensi politik dan hukum yang baru pasca jatuhnya rezim otoriter Presiden Soeharto.

Pada masa transisi otoriter menuju demokrasi, terdapat beberapa hal yang menjadi perhatian utama sebagai hal-hal yang harus diperbaiki. Rezim otoritarian memiliki satu kesamaan, yakni hubungan sipil - militer mereka tidak begitu diperhatikan. Dalam rezim militer otoritarian tidak ada control sipil, dan pemimpin serta organisasi militer sering melakukan fungsi yang luas dan bervariasi yang jauh dari misi militer yang normal, dimana pejabat militer memiliki unsur politis dan loyalitasnya lebih diutamakan kepada partai daripada negara. Hal ini menggambarkan hal pertama yang perlu diperbaiki adalah mengenai reposisi hubungan militer dan sipil dan kaitannya dengan partai politik.

Kemudian perumusan kebijakankebijakan baru dalam upaya mencapai keadilan dan perbaikan birokrasi juga diperlukan mengingat rezim otoriter pastinya meninggalkan sistem birokrasi yang berantakan dan hanya berorientasi pada keuntungan penguasa. Birokrasi publik di 
Indonesia masih lebih banyak menjadi bagian dari masalah daripada solusi dalam penyelenggaraan pemerintahan. Tentunya untuk mencapai sebuah sistem yang berpihak pada masyarakat, harus dirumuskan suatu sistem yang mampu menggantikan sistem yang lama dan memberi dampak langsung kepada masyarakat. Selain itu, aturan dan prinsip mengenai rekonsiliasi tupoksi lembaga-lembaga negara juga diperlukan untuk mendukung reformasi birokrasi tadi. Masalah lain yang menjadi fokus dari rezim baru dalam menata hukum yang baru pada masa transisi tentunya adalah berkaitan dengan Hak Asasi Manusia, sebuah hal yang menjadi isu bersama yang dialami oleh negara-negara demokrasi baru di dunia.

Banyaknya proses perubahan yang diperlukan ini tentunya harus dilandasi oleh kesepakatan mengenai sebuah prinsip awal dalam menata pemerintahan yang baru. Kembali pada perdebatan Hart dan Fuller, peneliti ingin melihat bagaimana rezim baru Indonesia pada masa transisi memposisikan hukum yang lama dan hukum yang baru, apakah kemudian sesuai dengan pendapat Hart, Fuller, ataukah sesuai dengan bagaimana idealnya pembentukan sebuah hukum di era transisi politik menuju demokrasi.

Berdasarkan latar belakang diatas, penulis tertarik untuk mengangkat makalah dengan judul "Perubahan Konstitusi dalam Transisi Orde Baru menuju Reformasi di Indonesia".

\section{Rumusan Masalah}

Berdasarkan ruang lingkup permasalahan diatas, penulis merumuskan permasalahan yang akan diteliti, yaitu:

1. Bagaimana kedudukan konstitusi yang lama terhadap konstruksi hukum rezim yang baru pada masa transisi politik reformasi di Indonesia?

2. Bagaimana dampak dari perubahan konstitusi dalam transisi orde baru menuju reformasi di Indonesia?

\section{Tujuan dan Manfaat Penelitian}

1. Tujuan Penelitian

Penelitian ini bertujuan untuk mengetahui, menganalisis dan memahami: a. Posisi ideal kedudukan konstitusi yang lama terhadap konstruksi hukum rezim yang baru dalam transisi politik menuju demokrasi.

b. Dampak Perubahan Konstitusi pada Transisi Orde Baru Menuju Reformasi di Indonesia Pada Masa Kini

2. Manfaat Penelitian

Penelitian ini mempunyai manfaat teoretis dan praktis. Secara teoretis penelitian ini diharapkan memberikan kontribusi dalam pengembangan ilmu pengetahuan hukum, terutama bidang Hukum Tata Negara dan Ilmu Pengetahuan Perundang-undangan, sedangkan secara praktis, hasil penelitian ini dapat menjadi bahan rekomendasi kepada pemegang kekuasaan membentuk peraturan perundangundangan, sehingga dalam setiap pembentukan peraturan perundang-undangan, senantiasa mempertimbangkan kebutuhan waktu dan kondisi politik yang labil pasca terjadinya transisi secara luar biasa untuk mempersiapkan peraturan pelaksanaan yang diperlukan sebagai pelaksanaan UndangUndang tertentu.

\section{KAJIAN PUSTAKA}

\section{Landasan Teori}

\section{Perubahan Konstitusi Pada Masa Transisi Politik Reformasi dalam Perspektif Stuffenbau Theorie}

Hukum di Indonesia merupakan campuran dari sistem hukum Eropa, hukum agama dan hukum adat. Sebagian besar sistem yang dianut, baik perdata maupun pidana, berbasis pada hukum Eropa Kontinental, khususnya dari Belanda karena aspek sejarah masa lalu Indonesia yang merupakan wilayah jajahan dengan sebutan Hindia Belanda (Nederlandsch-Indie). Sebagai negara berbasis Eropa Kontinental, tentunya aliran positivism sangat melekat sebagai salah satu inspirasi pada operasi-operasi hukum yang dilakukan oleh sistem ini, selain itu Eropa Kontinental terkenal dengan kepatuhannya pada hierarkhi dan hukum tertulis sebagai dasar hukum paling kuat, salah satu tokoh yang menginspirasi aturan teknis hierarkhi perundangan di dunia adalah Hans Kelsen, jadi dapat dikatakan Indonesia juga memiliki 
sebuah sistem yang terpengaruh oleh teori hierarkhi hukum Hans Kelsen.

Negara yang sistem hukumnya demokratis akan menciptakan kehidupan demokratis dalam segala bidang kehidupan. Demokratisasi hukum ditentukan oleh strategi pembangunan hukum yang dianut oleh suatu negara. Dari perspektif sejarah dikenal dua macam strategi pembangunan hukum yang menonjol dan berpengaruh. Kedua strategi pembangunan hukum yang dimaksud adalah:

1. Strategi pembangunan hukum "ortodoks", melahirkan tipe hukum "represif". Tipe hukum ini pada dasarnya melihat hukum sebagai alat kekuasaan agar dapat mempertahankan status quo, berusaha meminimalisasi arus tuntutan perubahan, termasuk upaya membentengi arus tuntutan perubahan dari public yang cenderung dianggap dapat mengganggu lestarinya kekuasaan.;

2. Strategi pembangunan hukum responsif, penekanannya adalah hukum sebagai legitimasi keinginan atau nilai-niali yang hidup dan berkembang dalam masyarakat. Ciriciri pembangunan hukum responsive adalah masyarakat berperan, negara tidak dominan.

Jika dicermati, pada proses transisi politik antara rezim orde baru menuju reformasi, ada upaya perubahan strategi pembangunan antar kedua rezim. Pada rezim orde baru dibawah pimpinan Presiden Soeharto selama 32 Tahun, pemerintah orde baru memilih menggunakan strategi pembangunan hukum represif dimana peran masyarakat begitu diminimalisir dengan tujuan untuk terus melanggengkan kekuasaan. Sementara itu, era reformasi mencoba merubah strategi pembangunan menuju hukum responsif dimana perubahan konstitusi diarahkan untuk lebih menimbulkan partisipasi masyarakat dan swasta, bersama pemerintah untuk kemudian membentuk segitiga integrasi sebagai stakeholder untuk mewujudkan ideal demokrasi yang sebenarnya. Maka dari itu, perubahan konstitusi menjadi suatu hal yang vital dalam masa transisi politik sehingga teknis perubahannya menjadi hal yang layak diangkat mengingat transisi yang terjadi pada era reformasi merupakan salah satu bentuk transisi luar biasa.

Konstitusi adalah hukum dasar yang dijadikan pegangan dalam penyelenggaraan suatu negara. Konstitusi dapat berupa hukum dasar tertulis yang lazim disebut Undangundang Dasar, dan dapat pula tidak tertulis. Hans Kelsen membagi jenjang norma hukum ke dalam dua jenjang, yakni jenjang norma yang tertinggi (grundnorm) dan jenjang norma yang ada di bawahnya sampai jenjang yang paling bawah. Lebih lanjut, Taufiqurrohman Syahuri, mengutip pendapat Hans Kelsen, menyatakan:

"Teori hierarki hukum (stuffenbautheory) menunjukkan norma hukum itu berjenjang dalam suatu tatanan susunan hierarki. Suatu norma yang lebih rendah berlaku dan bersumber atas dasar norma yang lebih tinggi, dan norma yang lebih tinggi itu, berlaku dan bersumber kepada norma yang lebih tinggi lagi. Demikian seterusnya sampai pada suatu norma yang tidak dapat ditelusuri, yang bersifat hipotetis dan fiktif, yaitu yang dikenal dengan istilah grundnorm (norma dasar). Norma dasar sebagai norma tertinggi itu dibentuk langsung oleh masyarakat dan menjadi sumber bagi norma-norma yang lebih rendah, oleh karena itu norma dasar itu disebut presuposed atau ditetapkan terlebih dahulu."

Mengenai norma dasar (grundnorm, basic norm, atau fundamental norm), Kelsen menyatakan bahwa sebagai norma tertinggi maka grundnorm tidak memperoleh validitasnya dari norma yang lebih tinggi karena dialah yang tertinggi. Grundnorm memperoleh validitasnya karena memang dipostulasikan valid. Dengan demikian, setiap norma dapat dinyatakan valid jika bersumber dari grundnorm yang dipostulasikan valid. Menyempurnakan teori Hans Kelsen, Hans Nawiasky kemudian mengemukan tata susunan norma hukum negara, yakni:

1. Staatsfundamentalnorm

(Norma Fundamental Negara);

2. Staatsgrundgezets (Aturan Dasar/Pokok Negara); 
3. Formell Gesetz (UU Formal);

4. Verordnung \& Autonome Satzung (Aturan Pelaksana dan Aturan Otonom).

Berdasarkan teori hierarki hukum

Kelsen dan Nawiasky, dikaitkan dengan hierarki peraturan perundangan di Indonesia, maka norma dasar sebagai norma tertinggi yang dibentuk langsung oleh masyarakat dan menjadi sumber bagi norma-norma yang lebih rendah di Indonesia adalah Pancasila. Sementara itu, dibawah Pancasila, hierarki perundang-undangan Indonesia dapat dilihat pada Pasal 7 ayat (1) Undang-undang Nomor 12 Tahun 2011 tentang Peraturan Perundangundangan dimana hierarkhinya adalah sebagai berikut:

a. Undang-Undang Dasar Negara Republik Indonesia Tahun 1945;

b. Ketetapan Majelis Permusyawaratan Rakyat;

c. Undang-Undang/Peraturan Pemerintah Pengganti Undang-Undang;

d. Peraturan Pemerintah;

e. Peraturan Presiden;

f. Peraturan Daerah Provinsi; dan

g. Peraturan Daerah Kabupaten/Kota.

Bertitik tolak dari teori hierarkhi Kelsen, diketahui bahwa Undang-undang Dasar Negara Republik Indonesia Tahun 1945 nyatanya bukan merupakan norma tertinggi, masih berada satu level dibawah norma dasar, yakni Pancasila. Pancasila sebagai norma dasar, norma tertinggi, dan sumber segala hukum dapat dilihat dalam Pasal 2 Undangundang No. 12 Tahun 2011 tentang Pembentukan Peraturan Perundang-undangan. Namun, pertentangan kemudian muncul lewat pernyataan Kelsen yang menyatakan bahwa berdasarkan hierarkhinya, sumber hukum tertinggi yang mendasari lahirnya suatu peraturan perundang-undangan dalam suatu negara menurut Kelsen adalah norma dasar ini bersifat presupposed, atau ditetapkan oleh masyarakat terlebih dahulu.

Artinya, norma dasar yang membentuk konstitusi dianggap sebagai sesuatu yang tidak tertulis yang telah berkembang sebagai nilai-nilai bermasyarakat, sementara itu Pancasila nyatanya dianggap sebagai sesuatu yang tertulis sehingga tidak tepat untuk dialamatkan sebagai grundnorm bagi bangsa
Indonesia. Namun kontroversi ini kemudian berujung pada pendapat para ahli hukum tata negara yang menyatakan bahwa Pancasila merupakan kristalisasi dari norma-norma yang berlaku pada masyarakat. Penguatan posisi Pancasila sebagai norma fundamental negara akan dibahas pada bagian berikutnya pada bab ini. Pada dasarnya, penulis menyetujui bahwa Pancasila merupakan norma fundamental negara dan pada bagian ini hanya akan fokus pada teori hierarki Kelsen sebagai sumber inspirasi hukum positif.

Melalui inspirasi yang hadir lewat teori hierarki Kelsen, maka berdasarkan Pasal 7 ayat (1) Undang-undang Nomor 12 Tahun 2011 tentang Pembentukan Peraturan Perundang-undangan, dari kata "hierarki", mengandung arti bahwa adanya penjenjangan setiap jenis peraturan perundang-undangan yang lebih rendah tidak boleh bertentangan dengan peraturan perundang-undangan yang lebih tinggi". Kelsen juga menyatakan bahwa apabila telah rusak salah satu norma yang lebih tinggi, maka akan ikut runtuh pula norma-norma yang ada dibawahnya.

Dikaitkan dengan proses reformasi, penggantian rezim tentunya membawa semangat baru terhadap strategi pembentukan hukum, namun Pancasila sebagai grundnorm tetap dipakai sebagai norma tertinggi dalam pembentukan hukum positif di Indonesia, singkatnya, kerusakan yang terjadi dalam piramida pada era Orde Baru adalah pada tingkatan konstitusi yakni Undang-undang Dasar Negara Republik Indonesia Tahun 1945. Merujuk pada piramida Kelsen, maka tidak ada keharusan untuk melakukan penggantian sistem hukum secara keseluruhan mengingat grundnorm yang digunakan masih tetap sama, namun adanya pembaruanpembaruan, upaya penegakan hukum otonom menuju hukum responsif untuk mencegah kembali terjadinya otoritarianisme lewat sistem yang represif mengharuskan perubahan pada beberapa titik tertentu dalam konstitusi, namun tidak semuanya, karena Pancasila masih menjadi sumber.

Artinya, pada kondisi yang terjadi di Indonesia, hukum dari rezim yang lama tetap mendapatkan porsi dan pengakuan oleh rezim 
yang baru, sepanjang gagasan-gagasan dan ide yang tersirat masih memiliki semangat yang sama dengan rezim yang baru, perubahan hanya diperlukan pada aturanaturan yang tidak memiliki semangat yang sama dengan rezim yang baru, misalnya pada perubahan regulasi dan pola sistem kelembagaan, pemilihan umum, dan peran serta masyarakat. Kesimpulannya, teori hierarki Kelsen sebagai sumber inspirasi hukum Indonesia menginginkan adanya pengakuan terhadap konstitusi yang ditinggalkan oleh rezim yang lama selama norma-normanya tetap disetujui dan dapat diterapkan oleh rezim yang baru.

Bertitik tolak dari perdebatan Hart dan Fuller, Indonesia lebih condong mengikuti pendapat Hart yang menyatakan bahwa pengakuan dan penghormatan terhadap hukum yang lama harus tetap dilakukan mengingat perubahan memerlukan prosedur, jatuhnya sebuah rezim bukan berarti jatuhnya sebuah sistem hukum secara otomatis sebagai sesuatu yang melekat kepada rezim sebelumnya. Sistem hukum baru dapat dinyatakan jatuh secara keseluruhan apabila norma fundamentalnya telah rusak, apabila kerusakan pada sistem norma bukan berasal dari sumber tertingginya, maka yang diperlukan hanyalah perubahan-perubahan untuk merevolusi sistem agar menjadi lebih baik mengingat sumber tertingginya yang masih berlaku sebagai sumber dari segala hukum positif bagi norma yang ada di bawahnya.

\section{Pancasila Sebagai Hukum Fundamental Negara Bagi Indonesia}

Menurut teori Kelsen-Nawiansky, grundnorm atau staatsfundamentalnorm adalah sesuatu yang abstrak, diasumsikan (presupposed), tidak tertulis, ia tidak ditetapkan, tetapi diasumsukan, tidak termasuk tatanan hukum positif, berada diluar namun menjadi dasar keberlakuan tertinggi bagi tatanan hukum positif, sifatnya metajuristic.

Teori

tentang staatsfundamentalnorm menjadi

hangat saat dilakukan amendemen Undangundang Dasar Negara Republik Indonesia Tahun 1945 pada tahun 1999-2002. Sebagian pihak ingin melakukan amendemen
Pembukaan Undang-undang Dasar Negara Republik Indonesia Tahun 1945 dengan berpendapat bahwa Pembukaan Undangundang Dasar Negara Republik Indonesia Tahun

bukanlah staatsfundamentalnorm (berdasarka $\mathrm{n}$ teori Kelsen-Nawiansky) sedangkan sebagian lagi mengikuti pendapat Notonagoro bahwa Pembukaan Undang-undang Dasar Negara Republik Indonesia Tahun 1945 adalah staatsfundamentalnorm yang

dituliskan sehingga tidak boleh diubah, kecuali dengan membubarkan negara.

Perdebatan mengenai posisi Pancasila yang tertuang secara eksplisit dalam Pembukaan Undang-undang Dasar Negara Republik Indonesia Tahun 1945 merupakan sesuatu yang vital mengingat posisi grundnorm merupakan posisi yang sangat penting dalam mengatur hukum positif yang ada agar sesuai dengan semangat bangsa. Apabila dicermati, perdebatan yang ada membahas seputaran prinsip hukum fundamental negara yang dikatakan oleh Kelsen-Nawiasky tidak bersumber dari norma lain dan merupakan sesuatu yang metajuristic, artinya tidak tertulis namun berlaku di masyarakat.

Pihak yang kontra terhadap Pancasila sebagai grundnorm menyatakan bahwa sebelum adanya Pancasila, Piagam Jakarta (Jakarta Charter) lebih dahulu ada. Kemudian terjadi perubahan isi pada poin pertama dengan menghapus tujuh kata; "Wajib menjalankan syari'at-syariat Islam bagi pemeluknya. "Kemudian namanya berganti menjadi Pancasila. Pendapat dan mungkin saya (Ibnu Arsib) yang pertama adalah, bahwa Pancasila bersumber dari Piagam Jakarta. Namun, penulis memiliki pandangan berbeda dimana Pancasila bukan bersumber dari Piagam Jakarta secara norma. Piagam Jakarta hanyalah sebuah agenda yang di dalamnya terdapat keinginan para pemimpin untuk merumuskan norma yang berkembang pada masyarakat untuk kemudian di kristalisasikan menjadi sebuah bentuk konkrit agar dapat dipertahankan secara turun-temurun sebagai falsafah bersama bagi bangsa Indonesia. 
Falsafah Pancasila berkembang dalam budaya dan peradaban Indonesia terutama sebagai jiwa dan asas kerokhanian bangsa dalam perjuangan kemerdekaan dari kolonialisme-imperialisme, falsafah Pancasila baik sebagai pandangan hidup (filsafat hidup, Weltanschauung) bangsa, sekaligus sebagai jiwa bangsa (Volksgeist, jatidiri nasional) memberikan identitas dan integritas serta martabat (kepribadian) bangsa dalam budaya dan peradaban dunia modern sekaligus sumber motivasi dan spirit bangsa Indonesia.

Penempatan Pancasila sebagai sebagai staatsfundamental-norm pertama kali disampaikan oleh Notonagoro. Pancasila dilihat sebagai cita hukum (rechtsidee) merupakan bintang pemandu. Posisi ini mengharuskan pembentukan hukum positif adalah untuk mencapai ide-ide dalam Pancasila, serta dapat digunakan untuk menguji hukum positif. Teori Notonagoro agak berbeda dengan teori Kelsen-Nawiasky. Notonagoro menyatakan bahwa Grundnorm bisa juga tertulis. Pancasila mengandung norma yang digali dari bumi Nusantara, semula tidak tertulis tetapi kemudian ditulis.

Pancasila sebagai dasar-dasar filosofis terdapat dalam Pembukaan Undang-Undang Dasar Negara Republik Indonesia Tahun 1945 yang merupakan kesepakatan pertama penyangga konstitusionalisme. Tidak diubahnya Pembukaan Undang-Undang Dasar Negara Republik Indonesia Tahun 1945 dalam amandemen, maka tidak berubah pula kedudukan Pancasila sebagai dasar-dasar filosofis bangunan Negara Republik Indonesia.

Jadi, mempersoalkan bahwa Pancasila memiliki sumber lain yakni dari Piagam Jakarta merupakan sebuah kesalahan, mengingat sumber yang dimaksud oleh teori Kelsen dan Nawiasky melihat dari perspektif sumber normanya. Faktanya Piagam Jakarta berisi norma yang sama dengan Pancasila, dimana Pancasila merupakan kristalisasi dari nilai-nilai yang tumbuh dan berkembang di masyarakat Indonesia. Hal ini menunjukkan adanya kesinambungan dari teori Kelsen, Nawiasky, Notonegoro, dimana Notonegoro menambahkan sebuah dimensi baru pada teori Kelsen-Nawiasky bahwa nyatanya Indonesia telah menunjukkan bahwa norma fundamental negara juga dapat dibakukan dalam sebuah bentuk konkrit yang tertulis asalkan norma tersebut masih berlaku secara menyeluruh dan diakui oleh bangsa sebagai norma tertinggi yang paling fundamental. Pada akhirnya dapat ditarik kesimpulan bahwa Pancasila merupakan norma fundamental, norma dasar yang dimiliki oleh Indonesia pada saat ini.

\section{HASIL DAN PEMBAHASAN}

Perubahan Perubahan dalam Konstitusi Pada Era Reformasi dalam Perspektif Teori Hukum Responsif Philippe Nonet dan Philip Selznick

Perubahan konstitusi pada proses transisi politik di Indonesia yang merupakan salah satu agenda dari era reformasi ditandai dengan amandemen pertama hingga keempat terhadap Undang-undang Dasar Negara Republik Indonesia Tahun 1945. Dalam menghadapi era transisi politik, sebuah negara demokrasi akan dihadapkan pada problematika besar terkait dengan arah strategi pembangunan hukum. Strategi pembangunan hukum dapat dibangun ketika problematika terkait hubungan produk hukum dari rezim yang lama dan baru dapat diselesaikan secara teknis. Hal ini telah dibahas dan dipecahkan pada bab sebelumnya bahwa Indonesia hanya perlu membuat, mengganti atau memperbaiki aturan-aturan yang diperlukan dalam rangka mewujudkan kesejahteraan melalui demokrasi.

Philippe Nonet dan Philip Selznick membagi pola evolusi hukum menjadi tiga tahapan, yakni:

1. Hukum Represif;

2. Hukum Otonom;

3. Hukum Responsif.

Hukum represif memberikan sedikit perhatian terhadap kepentingan-kepentingan orang yang diperintah, mengabaikan kepentingan tersebut dan menolak legitimasinya. Artinya pada masa penerapan hukum ini, terjadi upaya-upaya untuk melindungi kelanggengan kekuasaan sehingga terjadi diskriminasi terhadap hak-hak rakyat. Model kekuasaan seperti ini memiliki kelemahan dalam pemberian komando untuk menghadapi krisis mengingat domain aturan yang ada hanya bertujuan untuk 
melanggengkan kekuasaan semata. Puncaknya adalah jatuhnya rezim represif dan hukum berevolusi menuju hukum otonom.

Kompetensi utama dari hukum otonom adalah untuk membatasi kekuasaan penguasa dan melimitasi kewajiban rakyat. Dalam hukum otonom, sistem hukum menjadi sebuah sumber yang bertujuan untuk melindungi negara dari sifat represif. Namun penerapan hukum ini nyatanya hanya bisa dilakukan untuk jangka pendek saja, ada kebutuhan akan sebuah sistem yang lebih terbuka terhadap pengaruh sosial masyarakat mengingat hukum otonom yang formal dan berorientasi prosedural pada akhirnya menimbulkan permasalahan karena kurang efektif untuk berhadapan dengan permasalahan sosial, maka dari itu lahirlah sebuah tahapan yang menurut Nonet dan Selznick merupakan tahapan terakhir yang menjadi tujuan dari seluruh negara demokrasi, yakni hukum responsif.

Hukum responsif menganggap tekanan-tekanan sosial sebagai sumber pengetahuan dan kesempatan untuk memperbaiki diri. Melihat hukum sebagai institusi sosial, berarti melihat hukum itu dalam kerangka yang luas, yaitu yang melibatkan berbagai proses dan kekuatan dalam masyarakat. Seperti diungkapkan oleh Edwin M. Schur, sekalipun hukum itu nampak sebagai perangkat norma-norma hukum, tetapi hukum merupakan hasil dari suatu proses sosial, sebab hukum dibuat dan dirubah oleh usaha manusia dan hukum itu senantiasa berada di dalam keadaan yang berubah pula. Singkatnya, dalam hukum responsif, partisipasi masyarakat mendapatkan porsi baru dalam rangka mencapai tujuan bersama negara, mencapai kesejahteraan.

Dikaitkan dengan kondisi yang ada di Indonesia pada masa transisi era orde baru menuju reformasi, terdapat evolusi hukum yang terjadi di Indonesia yang sangat sesuai dengan perspektif teori dari Phillippe Nonet dan Philip Selznick. Era orde baru menampakkan sisi represif, ketika kebijakankebijakan yang diambil pemerintah mengabaikan kepentingan rakyat dan mengutamakan perlindungan pada kekuasaan.
Setelah itu, gerakan reformasi mencirikan adanya upaya perubahan pada konstitusi untuk mencegah terjadinya pemerintahan yang represif di masa depan. Selain itu, konstitusi juga diatur sedemikian rupa agar nantinya Indonesia mampu menerapkan hukum responsif, dimana amendemen yang dilakukan juga memungkinkan adanya partisipasi masyarakat melalui penegasan hakhak konstitusional rakyat yang menunjukkan adanya keseriusan dalam membentengi diri dari represifitas dalam pembangunan hukum di era reformasi.

Amendemen Undang-Undang Dasar 1945 sebagai amanat reformai pada akhirnya dapat dituntaskan dalam Perubahan keempat dengan nama resmi Undang-Undang Dasar Negara Republik Indonesia Tahun 1945. Perubahan empat kali itu dapat diperinci sebagai berikut:

1. Perubahan Pertama UUD 1945 yang ditetapkan pada tanggal 19 Oktober tahun 1999, berhasil diamandemen sebanyak 9 pasal.

2. Perubahan Kedua UUD 1945 yang ditetapkan pada tanggal 18 Agustus 2000 telah diamandemen sebanyak 25 Pasal.

3. Perubahan Ketiga UUD 1945 yang ditetapkan pada tanggal 9 November tahun 1999 berhasil diamandemen sebanyak 23 Pasal.

4. Perubahan Keempat UUD 1945 yang ditetapkan pada tanggal 10 Agustus 2002 ini telah berhasil diamendemen 13 pasal serta 3 pasal Aturan Peralihan dan 2 pasal Aturan Tambahan.

Jadi jumlah total pasal UUD 1945 hasil perubahan pertama sampai keempat itu adalah 75 pasal, namun demikian jumlah nomor pasalnya tetap sama yaitu 37 (tidak termasuk Aturan Peralihan dan Aturan Tambahan). Hal ini karena cara penulisan nomor pasal itu dilakukan dengan menambah huruf (A.B.C. dan seterusnya) setelah nomor angkanya. Kondisi semacam inilah yang menjadikan sistematika amendemen UUD 1945 tidak teratur.

Pokok-pokok sistem pemerintahan negara Indonesia berdasarkan UUD 1945 sebelum diamandemen atau pada masa orde baru tertuang dalam Penjelasan UUD 1945 
tentang tujuh kunci pokok sistem pemerintahan negara tersebut sebagai berikut:

1. Indonesia adalah negara yang berdasarkan atas hukum (rechtsstaat);

2. Sistem Konstitusional;

3. Kekuasaan negara yang tertinggi di tangan Majelis Permusyawaratan Rakyat;

4. Presiden adalah penyelenggara pemerintah negara yang tertinggi dibawah Majelis Permusyawaratan Rakyat;

5. Presiden tidak bertanggung jawab kepada Dewan Perwakilan Rakyat;

6. Menteri negara ialah pembantu presiden, menteri negara tidak bertanggungjawab kepada Dewan Perwakilan Rakyat;

7. Kekuasaan kepala negara tidak terbatas.

Berdasarkan tujuh kunci pokok sistem pemerintahan, sistem pemerintahan Indonesia menurut UUD 1945 menganut sistem pemerintahan presidensial. Sistem pemerintahan ini dijalankan semasa pemerintahan Orde Baru di bawah kepemimpinan Presiden Suharto. Ciri dari sistem pemerintahan masa itu adalah adanya kekuasaan yang amat besar pada lembaga kepresidenan. Hamper semua kewenangan presiden yang di atur menurut UUD 1945 tersebut dilakukan tanpa melibatkan pertimbangan atau persetujuan DPR sebagai wakil rakyat.

Sekarang ini sistem pemerintahan di Indonesia masih dalam masa transisi. Sebelum diberlakukannya sistem pemerintahan baru berdasarkan UUD 1945 hasil amandemen keempat tahun 2002, sistem pemerintahan Indonesia masih mendasarkan pada UUD 1945 dengan beberapa perubahan seiring dengan adanya transisi menuju sistem pemerintahan yang baru.Pokok-pokok sistem pemerintahan Indonesia pada masa reformasi adalah sebagai berikut:

1. Bentuk negara kesatuan dengan prinsip otonomi daerah yang luas. Wilayah negara terbagi dalam beberapa provinsi.

2. Bentuk pemerintahan adalah republik, sedangkan sistem pemerintahan presidensial.

3. Presiden adalah kepala negara dan sekaligus kepala pemerintahan. Presiden dan wakil presiden dipilih dan diangkat oleh MPR untuk masa jabatan lima tahun. Untuk masa jabatan 2004-2009, presiden dan wakil presiden akan dipilih secara langsung oleh rakyat dalam satu paket.

4. Kabinet atau menteri diangkat oleh presiden dan bertanggung jawab kepada presiden.

5. Parlemen terdiri atas dua bagian (bikameral), Dewan Perwakilan Rakyat (DPR) dan Dewan Perwakilan Daerah (DPD). Para anggota dewan merupakan anggota MPR. DPR memiliki kekuasaan legislatif dan kekuasaan mengawasi jalannya pemerintahan.

6. Kekuasaan yudikatif dijalankan oleh Makamah Agung dan badan peradilan dibawahnya.

Dengan demikian, ada perubahanperubahan baru dalam sistem pemerintahan Indonesia. Hal itu diperuntukan dalam memperbaiki sistem presidensial yang lama. Perubahan baru tersebut, antara lain adanya pemilihan secara langsung, sistem bikameral, mekanisme check and balance, dan pemberian kekuasaan yang lebih besar kepada parlemen untuk melakukan pengawasan dan fungsi anggaran. Adanya peran serta dari lembagalembaga perwakilan rakyat serta pengakuan terhadap otonomi daerah menunjukkan posisi Indonesia yang kini tengah dalam masa peralihan menuju penerapan hukum responsif, suatu hal yang positif untuk dijalankan oleh sebuah negara berbasis demokrasi.

\section{Arah Politik Hukum Pasca Reformasi di Indonesia}

Menurut Moh.Mahfud MD, politik hukum mencakup, sekurang-kurangnya tiga hal: Pertama, kebijakan negara (garis resmi) tentang hukum yang akan diberlakukan atau tidak diberlakukan dalam rangka pencapaian tujuan negara; Kedua, latar belakang politik, ekonomi, sosial, budaya (poleksosbud) atas lahirnya produk hukum; Ketiga, penegakan hukum di dalam kenyataan lapangan. Pada sub-bab sebelumnya, telah dijelaskan bahwa transisi politik dari era orde baru menuju reformasi membawa Indonesia mengubah strategi pembangunan hukumnya dari yang semula represif menuju responsif. Pada subbab ini akan dijelaskan kemana arah politik hukum pasca reformasi di Indonesia. 
Politik hukum nasional setiap negara dapat dibentuk, ditentukan oleh faktor-faktor, yaitu apa yang menjadi cita-cita suatu negara, rakyat atau tergantung pada kehendak pembentuk hukum, tradisi atau teoritisi latar belakang tradisi dan realita sosial setiap negara, realita hukum dan pengembangan hukum nasional dan realita dunia Internasional. Dalam sepanjang sejarah Negara Republik Indonesia telah terjadi perubahan-perubahan politik secara bergantian (berdasar periode sistem politik) antara konfigurasi politik yang demokratis dan konfigurasi politik yang otoriter. Pada saat konfigurasi politik tampil secara demokratis, maka produk-produk hukum yang dilahirkannya bersifat responsive, sebaliknya ketika konfigurasi politik tampil secara otoriter, hukum-hukum yang dilahirkannya bersifat ortodoks.

Arah pembangunan hukum pasca reformasi adalah keinginan untuk membangun hukum yang responsif. Membangun hukum yang responsif harus diawali dengan demokratisasi dalam kehidupan politik. Tidaklah mungkin kita membangun hukum yang responsif tanpa terlebih dahulu membangun sistem politik yang demokratis, sebab hukum responsif tidak mungkin lahir di dalam sistem politik yang otoriter. Melalui amandemen konstitusi (1999-2002) Indonesia telah membuat struktur dan pola hubungan kekuasaan negara yang dari sudut ketatanegaraan lebih menjamin tampilnya sistem yang demokratis. Hal ini menunjukkan bahwa strategi hukum pasca reformasi dibangun diatas prinsipprinsip demokrasi meskipun masih terdapat kekurangan dalam implementasinya.

\section{KESIMPULAN}

1. Pada masa transisi orde baru menuju reformasi, tidak terjadi perubahan terhadap pembukaan Undang-Undang Dasar Negara Republik Indonesia Tahun 1945 yang isinya memuat Pancasila. Pada era reformasi, masih berlakunya Pancasila sebagai norma tertinggi memberikan kedudukan yang tetap pada hukum era orde baru, pemerintahan rezim reformasi hanya perlu melakukan perubahanperubahan terhadap aturan-aturan yang dirasa sudah tidak sesuai dengan Pancasila dan tidak masuk pada rencana pembangunan Indonesia untuk masa yang akan datang. Jadi pada masa transisi otoriter menuju demokrasi di Indonesia, tidak diperlukan konstitusi yang benarbenar baru mengingat norma tertinggi yang masih berlaku sehingga yang diperlukan hanya merevitalisasikan konstitusi yang lama untuk keluar dari jerat pola represif menuju pola baru, yakni responsif.

2. Arah politik hukum di Indonesia pasca reformasi adalah keinginan untuk membentuk sistem hukum yang responsif, hal ini secara tersirat dapat dilihat dalam beberapa perubahan pada konstitusi. Perubahan menuju hukum yang responsif bukanlah sesuatu yang instan dan mudah, harus ada komitmen dari negara dan rakyat secara bersama untuk mewujudkan ideal pada sistem ini. Meskipun implementasi hukum saat ini masih mengalami banyak kesalahan disana-sini, namun setidaknya produk hukum yang ada sudah mengarah pada hukum yang responsif, yang dibutuhkan saat ini adalah figur-figur pemimpin yang mampu membawa Indonesia kepada penerapan hukum responsif yang sesuai dengan apa yang diharapkan sebelumnya dalam rangka mencapai kesejahteraan bagi rakyat.

\section{SARAN}

1. Demokratisasi pada kehidupan politik harusnya dipelopori oleh partai politik terlebih dahulu, saat ini partai politik yang semestinya menjadi institusi yang ikut membantu mencerdaskan kehidupan bangsa dalam bidang-bidang ilmu politik justru menampilkan politik pragmatis yang hanya berorientasi pada kekuasaan, bukan pada pembangunan masyarakat politik yang berkelanjutan.

2. Saat ini, tujuan hukum pasca reformasi belum mencapai puncaknya, namun gagasan mengenai amendemen kelima sudah hadir dari berbagai kalangan, terutama politisi. Perubahan ini tentunya akan mereset ulang semua sistem yang telah dibangun sebelumnya. Hal ini 
bukannya hal yang baik, mengingat saat ini yang diperlukan bukanlah perubahan sistem, melainkan sebuah optimalisasi dalam penerapan regulasi dan pemerintahan terhadap rakyat. Jadi muatan konstitusi harus dipertahankan dari dinamika-dinamika politik dan perubahan konfigurasi politik yang tentunya bisa membuat perjuangan reformasi menjadi sia-sia, apalagi sampai harus mereset sebuah sistem, mulai dari awal.

\section{DAFTAR PUSTAKA}

Agus Dwiyanto.

Mengembailkan

Kepercayaan Publik Melalui

Reformasi Birokrasi. Jakarta:

Gramedia, 2011.

Budiono Kusumohamidjojo. Teori Hukum: Dilema antara Hukum dan Kekuasaan. Bandung: Yrama Widya, 2016.

Dani Pinasang. Pembudayaan Nilai Pancasila. Makalah disajikan dalam Focus Group Discussion (FGD) MPRRI. bekerjasama dengan Universitas Brawijaya(UB), 2010.

Herlambang Perdana Wiratraman. Hierarki Peraturan. Bahan Ajar Hukum Perundang-Undangan. Surabaya: Departemen Hukum Tata Negara, 2007.

Jimly Asshiddiqie. Konstitusi dan Konstitusionalisme Indonesia. Jakarta: Konstitusi Press, 2005.

Jimly Asshiddiqie dan Ali Syafa'at. Pandangan Hans Kelsen tentang Hukum. Jakarta: Konstitusi Press, 2006.

Joseph Raz. The Concept of A Legal System. New York: Clarandom Press Oxford, 1980.

Moh.Mahfud MD. Politik Hukum di Indonesia. Jakarta: RajaGrafindo, 2014.

Notonagoro. Pancasila Dasar Falsafah Negara, Jakarta: Pantjuran Tudjuh.

Philippe Nonet dan Philip Selznick diterjemahkan oleh Raisul Muttaqien. Hukum Responsif. Bandung: Nusamedia, 2013.
Philippe Nonet dan Philippe Zelnick. Law and Society in Transition in Toward Responsive Law. New York: Harper Colophon Book, 1997.

Satjipto Rahardjo. Hukum dan Masyarakat. Bandung: Angkasa, 1980.

Satya Arinanto. Hak Asasi Manusia dalam Transisi Politik di Indonesia. Jakarta: Pusat Studi Hukum Tata Negara, 2018.

Satya Arinanto. Politik Hukum 1. Jakarta: Fakultas Hukum Universitas Indonesia, 2018.

Satya Arinanto. Politik Hukum 2. Jakarta: Fakultas Hukum Universitas Indonesia, 2018.

Taufiqurrohman Syahuri. Tafsir Konstitusi berbagai Aspek Hukum. Jakarta: Prenada Media Group, 2011.

Teguh Prasetyo dan Abdul Halim Barkatullah. Filsafat, Teori, dan Ilmu Hukum: Pemikiran Menuju Masyarakat yang Berkeadilan dan Bermartabat, Jakarta: RajaGrafindo, 2016.

Yuliandri. Asas-asas Pembentukan Peraturan PerUndang-Undangan Yang Baik Gagasan Pembentukan UndangUndang Berkelanjutan. Jakarta: Rajawali Pers, 2013.

Republik Indonesia. Undang-Undang Dasar Negara Republik Indonesia Tahun 1945. Jakarta: Sekretariat Jenderal MPR RI, 2002.

Republik Indonesia. Undang-Undang tentang Pembentukan Peraturan PerundangUndangan. UU Nomor 12 Tahun 2011. LN Tahun Nomor 82, TLN Nomor 52

Abdul Halim. Misteri Kekuasaan 32 Tahun Soeharto. http://www.voaislam.com $/ \mathrm{read} /$ citizensjurnalism/2014/12/14/34500/misteri32-tahun-kekuasaan-mantan-presidensoeharto. diakses pada 17 Maret 2020, pukul 19.15.

Sekretariat Negara. Kontroversi Amendemen $U U D$ 1945. http://www.setneg.go.id/index.php?Ite $\underline{\text { mid}=195 \& i d=1695 \& \text { option }=\text { com cont }}$ 
ent\&task=view, diakses pada 17 Maret 2020, pukul 20.54.

Ibnu Arsib. Apakah Pancasila Norma Dasar Tertinggi Dalam Sistem Hukum Norma di Indonesia. https://yakusaaa.com/2017/11/apakahpancasila-norma-dasar-tertinggi.html, diakses pada 19 Maret 2020, pukul 22.41 . 